\title{
Los intelectuales y la política en la revolución mexicana: estudio de casos
}

Susana Quintanilla CINVESTAV-IPN

Presentación

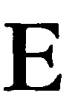
1 tema de la participación de los intelectuales en el proceso revolucionario de 1910 ha suscitado, en el curso de los últimos años, una polémica aún abierta ${ }^{1}$ que invita $a$ observar las relaciones entre el intelectual y el poder desde nuevas perspectivas, menos dispuestas a emitir juicios rápidos y más preocupadas por los hombres y su entorno. Invita, también, a realizar estudios de caso que den cuenta de la percepción y el compor-

1 Camp, Intelectuales, 1988; Knight, "Intelectuales", 1989; Monsiváis, "Aparición", 1985; Quintanilla, "Ateneo", 1990; Saborit, "Inercias", 1985; Schmidt, "Intelectuales", 1982. tamiento de las elites culturales durante la revolución y de las estrategias que éstas desarrollaron para sobrevivir a los cambios, si no para acrecentar, sí por lo menos para mantener su prestigio e influencia dentro de la sociedad mexicana.

El grupo reunido en torno al Ateneo de la Juventud es un ejemplo singular para el análisis de los problemas enunciados. Formada en la bella época del porfiriato, ${ }^{2}$ esta generación sobrevivió a la contienda para colocarse en la cresta de aquella ola surgida en las postrimerías del siglo XIX, ganó vigor con la revolución y finalmente alcanzó su mayor fuerza du-

2 Quintanilla, "Formación" (en prensa). 


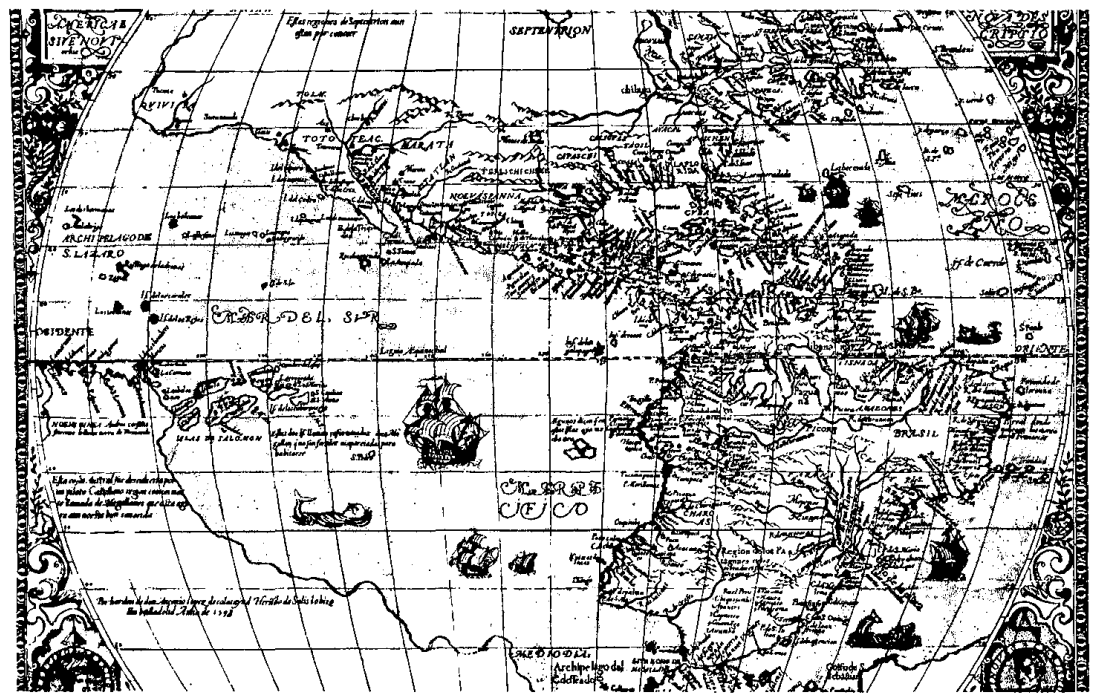

rante los años veinte. Sus integrantes padecieron un mundo convulsionado por las guerras, la mexicana y la europea, y fueron testigos de transformaciones vertiginosas. Como en los grandes dramas, en el de su vida confluyen, ya sea para fusionarse o para chocar, personalidades conflictivas e intensas, circunstancias irrepetibles y pasiones desbordaclas. ${ }^{3}$

Campo fértil para cultivar la condena o la prédica, la pregunta acerca del papel que desempeñó el Ateneo en la revolución mexicana ha suscitado opiniones contrarias. Durante mucho tiempo prevaleció la tesis de que el pensamiento de la pléyade ateneísta, su lucha contra el positivismo en favor de nuevas pautas cul-

3 Uría Santos, "Ateneo", 1965. turales, formó parte del movimiento nacional contrario a la dictadura y, más tarde, al proyecto revolucionario triunfante. ${ }^{4}$ Desde esta perspectiva, defendida, entre otros, por Vicente Lombardo Toledano, ${ }^{5}$ el programa cultural encabezado por el Ateneo fue, en el terreno de las ideas, lo que el maderismo en la política: el despertar de una conciencia que llegaría a triunfar en nuestro país.

4 Esta interpretación fue sugerida por los propios ateneístas, quienes en sus memorias y ensayos autobiográficos resaltaron la labor de su generación en la lucha cultural e ideológica contra la dictadura. Henríquez Ureña, Ensayos, 1984, pp. 249-260, 288-297; Reyes, "Pasado", 1967, p. 129; Vasconcelos, "Movimiento", 1962, pp. 117-134; "Juventud", 1962, pp. 135-138.

5 Lombardo Toledano, "Sentido", 1962, p. 178. 
Esta tesis, manejada hasta el cansancio por la retórica oficial, ha sido rebatida por quienes afirman que la revolución no contó con guías ideológicas precisas, ${ }^{6}$ no tuvo a una intelligentsia capaz de formular doctrinas que acompañaran y dieran forma a los reclamos populares. ${ }^{7}$ Dado el giro campesino y popular que tomó el conflicto tras la caída de Huerta, la intelectualidad urbana, que desempeñara un papel decisivo en los albores de la gesta revolucionaria, pasó a ocupar un sitio marginal. ${ }^{8}$ Aislados del pueblo, los ateneístas fueron sólo espectadores pasivos e incrédulos de la tragedia. ${ }^{9}$ En los escasos momentos en que algunos de ellos salieron de la torre de marfil para elaborar reformas o asesorar a los caudillos, fueron desoídos por sus protectores. ${ }^{10}$

En este debate ha prevalecido una historiografia sustentada en grandes interpretaciones que oscilan entre dos polos: a) la idea convencional de los intelectuales como seres aislados de la política, al margen de los juegos del poder; $b$ ) la noción del intelectual como representante de una clase social, como agente del Estado y como creador de ideologías que encubren la realidad. ${ }^{11}$ El primer modelo hizo suya la imagen de la revolución como una epopeya heroica del pueblo mexi-

6 Tannenbaum, Peace, 1933, pp. 114-117.

7 Katz, "Villa", 1989, pp. 92-94; "Intelectuales", 1991, p. 5.

8 Knight, "Intelectuales", 1989, pp. 38-40.

9 Krauze, "Pasión", 1983, pp. 87-88; Monsiváis, "Aparición", 1985.

${ }^{10}$ Cosío Villegas, "Intelectual", 1985, p. 77.

II Brunner, Intelectuales, 1981, presenta una síntesis de las diversas concepciones acerca del intelectual. cano dirigida a acabar con los males de la dictadura y a instaurar un régimen más justo y democrático. El segundo ubica al proceso revolucionario como un movimiento clasista, ${ }^{12}$ dentro del cual los intelectuales promovieron los intereses del bloque triunfante y legitimaron el orden impuesto tras la derrota de la dictadura.

Este trabajo se inscribe dentro de la polémica esquemáticamente descrita e intenta contribuir a ella mediante el análisis de las relaciones entre algunos intelectuales del Ateneo y la vida política durante los años 1909 . 1916. En la muestra estudiada (que de ningún modo abarca a la pléyade cuantitativamente amplia y heterogénea en cuanto a su composición $)^{13}$ se hallan representadas tanto la fracción del Ateneo que durante el periodo estudiado hizo de la política una forma de

12 Comparto la crítica hecha por Knight, "Revolución", 1986, a estas interpretaciones de la revolución.

13 El grupo reunido en torno al Ateneo de la Juventud fue mucho más amplio y heterogéneo de lo que comúnmente se supone. En él confluyeron intelectuales de generaciones anteriores y personalidades con trayectorias, ideologías, posturas políticas profesionales e intereses variados. Genaro Fernández MacGregor, Ateneo, 1960 , p. 2 , presenta una lista de cerca de 60 miembros fundadores del Ateneo, entre los que destacan los siguientes nombres: Luis Cabrera, Antonio Caso, Erasmo Castellanos, Alfonso Cravioto, Genaro Fernández MacGregor, Nemesio García Naranjo, Ricardo Gómez Robelo, Martín Luis Guzmán, Max y Pedro Henríquez. Ureña, José María Lozano, Eduardo Pallares, Alberto J. Pani, Manuel M. Ponce, Alfonso Pruneda, Alfonso Reyes, Diego Rivera, Jose Santos Chocano, Mariano Silva y Aceves, Julio Torri, Luis G. Urbina, Jesús Urueta, José Vasconcelos y Ángel Zárraga. 
vida (Pani, Palavicini, ${ }^{14}$ Cabrera, Cravioto, García Naranjo y Vasconcelos) como aquella que se dedicó a la labor estrictamente intelectual: Reyes, Caso y Henriquez Ureña. Intenté también dar cabida a intelectuales con posiciones políticas divergentes y cuyas trayectorias, durante la etapa analizada, fueran distintas. Algunos de sus actos nos pueden parecer reprobables; otros, dignos de admiración. Más que aventurar juicios, lo que se pretende es observar las reacciones de estos personajes ante los acontecimientos revolucionarios, sus nexos con las distintas fuerzas en pugna y sus vínculos con el poder.

\section{TIEMPO NUEVO}

En México, la visión del intelectual en cuanto ser separado de la esfera política, con funciones fijas y espacios independientes de la administración pública, fue producto de un largo proceso en el que cumplieron un papel decisivo la división del trabajo urbano, el desarrollo de las ciudades y el crecimiento de la enseñanza superior. ${ }^{15}$ La vida personal y las acciones e ideas de los intelectuales de antaño estaban enmarcadas dentro de los límites del Estado; hacia ahí dirigían su atención, poniendo en juego valores de lealtad a fin de mantener y acrecentar su prestigio e influencia social. ${ }^{16} \mathrm{La}$

14 Si bien Félix F. Palavicini no fue miembro del Ateneo, consideré pertinente incluirlo dentro de esta generación.

15 Camp, Intelectuales, 1988.

16 Aun para un autor con público y prestigio como Federico Gamboa, el "ritual" de acudir al dictadura fue un terreno fecundo para la cosecha de vínculos corporativos, de apoyo y servicios mutuos, entre los hombres de ideas y el gobierno. Véase, si no, el espectáculo ofrecido por la Unión Liberal ${ }^{17}$ en el circo político porfiriano, o el fracaso de los poetas del modernismo, quienes fueron los primeros en considerar al artista como un profesional cuya relación con la sociedad era de naturaleza particular. ${ }^{18}$

Los fundadores del Ateneo de la Juventud, creado en 1909 , siguieron la ruta trazada por sus maestros, en un momento en el cual los pilares del viejo régimen comenzaban a resquebrajarse. Si bien estaba prohibido que en las reuniones de la asociación se tocaran temas políticos, buena parte de sus socios pertenecía a uno u otro bandos en pugna con motivo de la sucesión presidencial. Este dato no debe sorprendernos: en aquel tiempo, era común que los recién egresados y los estudiantes de las escuelas superiores iniciaran su carrera incorporándose a algún grupo político, bajo la tutela de un amigo o tutor. Ser miembro de una camarilla de la corte porfirista era requisito insoslayable dentro de un mercado de influencias en el que la protección funcionaba como principio básico de la vida social. 19

Disuelto el reyismo, movimiento que atrajo la simpatía de muchos jóvenes intelectuales, algunos ateneístas (menos de los que comúnmente se su-

Ministerio de Instrucción, a cargo de Justo Sierra, para obrener "favores" resultaba inevitable. Gamboa, Diario, 1977, pp. 96-97.

17 Raat, "Ideas", 1973; "Antipositivist", 1977.

18 Franco, Cultura, 1983, pp. 53-57.

19 González, Todo, 1989, pp. 153-175. 
pone) engrosaron las filas de Madero. La incapacidad del gobierno para satisfacer las demandas abiertas por la expansión del sistema escolar, ${ }^{20}$ los efectos negativos de la crisis económica sobre las capas medias urbanas ${ }^{21}$ y la esclerotización de un sistema que obstaculizaba el ascenso de las nuevas generaciones a los puestos de dirección han sido frecuentemente señaladas como las causas explicativas. Las elites ilustradas, que crecieron al ritmo del progreso porfirista, hicieron suyas las proclamas de Madero y depositaron en él sus esperanzas de movilidad social. 22

A la luz de estudios recientes acerca de la época, esta explicación resulta insuficiente. Como indica Alan Knight, el malestar de la intelligentsia porfiriana no tuvo como causa única, ni siquiera determinante, el deterioro de la economía. ${ }^{23}$ Otros factores pudie. ron ser decisivos, e incluso es factible que las transformaciones en la cultura y en la educación precedieran y otorgaran un giro inesperado a los cambios en las estructuras política y económica. Si bien muchos intelectuales adoptaron el programa civil propuesto por Madero, mismo que no atentaba, por lo menos en un principio, contra las bases sociales del porfi-

20 Guevara, Luchas, 1983, t. 1, pp. 34-37.

21 Ruiz, "Justo", 1970, pp. 51-52.

22 Esta tesis tiene sus orígenes en la extensa bibliografía producida por intelectuales y dirigentes políticos de la época acerca de los suce. sos revolucionarios. La obra de Bulnes, El verdadero Diaz y la Revolucion ha sido referencia básica para "documentar" la existencia de un "proletariado intelectual" inconforme, desatendido por el gobierno.

${ }^{23}$ Knight, "Intelectuales", 1989, pp. 34-36. riato, ello ocurrió porque éste recuperaba la tradición liberal ${ }^{24}$ transmitida por la familia y firmemente enraizada en la escuela pública. ${ }^{25}$ Asimismo, el movimiento antirreeleccionista dio cabida a nuevas formaciones culturales entonces en boga: ${ }^{26}$ desde el romanticismo anticapitalista de finales de siglo hasta el pensamiento católico renovador. Pese a sus diferencias, estas vertientes tenían rasgos comunes: su tono moralizante y misionero, un sentido del cambio sobre la base del esfuerzo colectivo e individual. Aunque expuesta de maneras muy diversas, la creencia en la posibilidad y la urgencia del cambio fue decisiva en la conformación del sentir y del pensamiento reformador prerrevolucionario. ${ }^{27}$

Lo anterior ayuda a explicar el porqué varios miembros del Ateneo con historias personales e ideas tan distintas -como Luis Cabrera, Alfonso Cravioto, Alberto J. Pani, Jesús Urueta y José Vasconcelos- simpatizaran con la oposición. En uno de los polos de

${ }^{24}$ El peso de la tradición liberal en la conformación del movimiento opositor y, más tarde, del proyecto revolucionario ha sido destacado, entre otros, por: Cockcroft, Precursores, 1976; Córdova, Ideologia, 1973 y Guerra, México, 1988.

${ }^{25}$ Sobre la transmisión del dogma liberal en la escuela y la familia, véanse: Guerra, México, 1988, vol. I, pp. 426-445; Knight, "Intelectuales", 1989, pp. 42-50; Quintanilla, "Formacion" pp. 511 (en prensa); Vaughan, "Primary", 1988.

26 Schmidt llama la atención sobre la proliferación, durante el cenit del porfiriato, de nuevas vertientes culturales como el intuicionismo y la metafísica, que desempeñaron un papel importante en la crítica a la filosofia positivista y la dirección de la cultura posrevolucionaria. Schmidt, "Intelectuales", 1982, pp. 75-76.

27 Steiner, Castillo, 1991, pp. 100-109. 
este elenco podemos ubicar a Luis Cabrera, quien sintetiza la trayectoria de esa nueva generación de liberales formada en el periodismo independiente, afin a Reyes y con experiencia en el análisis social y político. ${ }^{28}$ En el otro polo está José Vasconcelos, quien no contaba con antecedentes en el campo de la política. Las esperanzas de ascender la rígida muralla social fueron, sin duda, determinantes en la decisión de Vasconcelos de afiliarse al Partido Antirreeleccionista, 29 pero en ella se pusieron en juego otros procesos, tales como su identificación con los principios liberales de la clase media del norte del país ${ }^{30}$ y las tesis apostólicas maderistas. Inclinado,

28 Beer, Luis, 1984, pp. 37-62.

29 Skirius, "Vasconcelos", 1984, p. 57.

30 Blanco, se llamaba, pp. 57-58. desde su niñez, hacia los fenómenos inexplicables, la filosofia del "Apóstol de la democracia" pudo haberlo incitado a la búsqueda de un vínculo entre el espiritismo, al que sabemos era devoto, y la actividad política. ${ }^{31}$

El caso de Alfonso Cravioto es, en muchos sentidos, excepcional. Fue el único de nuestros protagonistas que participó en los albores del Partido Liberal y en las luchas estudiantiles encabezadas por los hermanos Flores Magón. Su despertar político coincidió con la caída del poder caciquil que durante años ejerció el clan Cravioto en el estado de Hidalgo. Tras la represión gubernamental contra los clubes liberales, abandonó temporalmente la militancia para dedicarse a

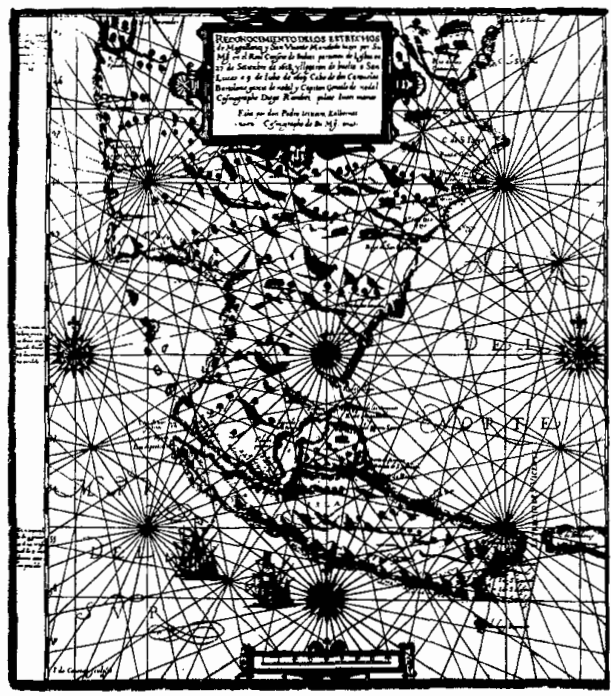


promover la cultura. Tiempo después se uniría a las filas del maderismo. ${ }^{32}$

Las funciones desempeñadas por estos intelectuales dentro del movimiento opositor fueron de orden propagandístico y organizativo, en un momento en el que la lucha por la conquista de la opinión pública cumplia un papel destacado y el debate en torno a la democracia, el futuro del país y la necesidad de implementar reformas estaba en su apogeo. ${ }^{33}$ No menos trascendental fue la labor de algunos ateneístas en la elaboración de esa compleja red de relaciones lograda por el maderismo durante la campaña electoral. Félix Palavicini, miembro de la mesa directiva del Centro Antirre. eleccionista, acompañó a Madero en su gira por algunos estados de la república, fungiendo como organizador, escriba y orador. Más tarde, fue

32 Alfonso Cravioto nació en Pachuca, Hidalgo, en 1884. Su padre fue un general juarista que combatio contra Maximiliano. Muerto Juárez, se unió a Díaz, por quien fue favorecido hasta 1887, año en que comenzo a declinar el poder caciquil que los Cravioto ejercieron en Hidalgo. En 1899, Alfonso ingresó en Ios núcleos liberales hidalguenses; hacia 1901 fue director de El Desfanatizador, órgano periodístico de estos grupos. En ese mismo año participó en el Congreso Liberal de San Luis Potosí, donde conoció a los hermanos Flores Magón. Meses despues, se traslado, a la ciudad de México, donde ingresó en la agrupación estudiantil "Ignacio Ramírez". Asistió como dele. gado a la reinstalación del Club Liberal Ponciano Arriaga (19.03) y formó parte de su mesa directiva. Tras la muerte de su padre, y ya alejado de la política, patrocinó y dirigio la revista Savia Moderna, de la cual habria de nacer la Sociedad de Conferencias y Conciertos y, más tarde, el Ateneo de la Juventud. Granados Chapa, Alfonso, 1984 , pp. 10-89.

33 Cosío Villegas, "Cómo", 1985, pp. 123144.

LOS INTELECTUALES Y LA POLÍTICA encargado de reestructurar el Antirreeleccionista, periódico en el que José Vasconcelos publicó sus primeros estudios filosóficos, ùn ensayo sobre el baile y los artículos políticos que desdencadenarian su primer exilio. ${ }^{34} \mathrm{Mu}$ cho más contundente fue la labor periodística de Luis Cabrera, cuyos escritos de aquel entonces, firmados con el seudónimo de Blas Urrea, le darían la justa reputación de haber sido uno de los activistas intelectuales más lúcidos de la época. 35

Contrariamente a lo que se piensa, no toda la generación de El Ateneo fue maderista. Una fracción nada despreciable de sus miembros apoyó la fórmula Díaz.Corral. Preocupados ante el giro desfavorable que tomaban los acontecimientos, algunos dirigentes del partido científico pugnaron por abrir las puertas de esta agrupación a los jóvenes que por aquel entonces comenzaban a destacar en la escena pública. Su iniciativa tuvo éxito, $e$ incluso hubo quienes (como el ateneísta José Ma. Lozano) rectificaron su postura en contra de los "científicos" para colaborar con ellos en la campaña por la presidencia. ${ }^{36} \mathrm{Y}$ es que la falta de un mercado de consumo cultural independiente del Estado obligaba a la intelectualidad a vivir bajo el ala protectora del gobierno, con la certidumbre de que las disenșiones nunca debían expresarse en público sino internamente y bajo el control del poder. ${ }^{37}$

El caso de Nemesio García Naranjo es representativo de esta relación en-

34 Palavicini, Vida, pp. 25-69.

35 Cabrera, Obras, 1921.

36 García Naranjo, Memorias, vol. v, pp. 139152.

37 Monsiváis, "Notas", 1975, pp. 319-326. 
tre los intelectuales y los hombres de gobierno. Tras dejar su vida de "crápula sin esplendor" en el barrio estudiantil, hizo una exitosa carrera pública sustentada en los vínculos de su familia con algunos miembros del gabinete. ${ }^{38}$ Su fobia por el general Bernardo Reyes (una fobia que venía de tiempo atrás, cuando Reyes fracturó el poderío del clan Naranjo en Nuevo León), ${ }^{39}$ la lealtad para con quienes le habían cado protección, así como el deseo de obtener una curul en el Congreso, lo orientaron hacia el bando de Ramón Corral. Ahí se encontraban los ateneístas Hipólito Olea, José María Lozano y Ricardo Gómez Robelo. ${ }^{40}$ Aunque en forma menos abierta, Antonio Caso, quien al decir de José Vasconcelos juzgaba a Díaz como "el mal menor de un pueblo inculto, sin esperanza" ${ }^{41}$ fue también miembro de esta asociación. De acuerdo con el testimonio de Nemesio García Naranjo, en sus intervenciones públicas Antonio Caso sobresalía por su inquina en contra de la oposición. ${ }^{42}$

38 García Naranjo descendía del clan de caudillos militares que, dirigido por los generales Treviño y Naranjo, durante décadas gobernó al estado de Nuevo León.

39 Inconforme con el derrocamiento del gobernactor de Nuevo León, Genaro Garza, el padre de García Naranjo organizo por parte del gobierno federal un grupo armado, mismo que fue derrotado por la guarnición del general Bernardo Reyes, nuevo protegido del dictador. Tras la derrota, se exilió con su familia en Texas, donde habría de vivir doce ańos. García Naranjo, Memorias, 1963, vol. I, pp. 120-128.

t0 García Naranjo, Memorias, vol. v, 1963 , pp. 82-168.

41 Vasconcelos, Ulises, 1983, vol. II, p. 333.

12 La participación de Antonio Caso en la campana reeleccionista ha sido pasada por alto por sus biógrafos y discípulos.
Resulta dificil explicar la alianza política entre una intelectualidad que se distinguiría por su lucha contra la doctrina positivista y el poderoso grupo de los "científicos", al cual se debió, en buena medida, la difusión de la filosofia de Comte en nuestro país. ${ }^{43}$ Es cierto que hubo oportunismo en ambos bandos, cuyos intereses inmediatos estaban por encima de sus posibles diferencias filosóficas. Estas últimas no eran, sin embargo, tan profundas e irreconciliables como se nos ha hecho creer. Es sabido que el Ateneo de la Juven. tud gozó del apoyo tanto de algunos miembros del gabinete aún identificados con el positivismo, como del ministro de Instrucción Pública, Justo Sierra. ${ }^{44}$ Tiempo atrás, este último había renegado de las verdades comtianas, declarándose públicamente espiritualista ${ }^{45} \mathrm{Su}$ proyecto de crear la Universidad Nacional, mismo que fue blanco de virulentos ataques por parte de los editores de la Revista Positiva, sería apoyado por la pléyade del Ateneo, la cual hizo suya la empresa iniciada por su maestro. ${ }^{46}$

Las desavenencias políticas de los ateneístas no impidieron que el Ateneo de la Juventud desplegara su labor cultural. Gracias a su declarado apoliticismo y a su autonomía con respecto a las fuerzas en pugna, logró atraer a

43 Raat, "Ideas", 1973.

44 La serie de conferencias del Ateneo, en 1910, fue patrocinada por Justo Sierra y Ezequiel A. Chávez. Ia edición del texto fue pagada por Pablo Macedo, director de la Escuela de Jurisprudencia.

45 O'Gorman, "Sierra", 1948.

46 Hernández Luna, "Universidad", 1967; Villegas, "Fundación", 1984. 
intelectuales de las más variadas orientaciones ideológicas y simpatías partidarias. Y es que el Ateneo-de ahí su éxito- no fue el órgano de una comunidad religiosa ni de un partido político. Fue, en todo caso, la voz de una juventud urbana que aspiraba a una cultura más moderna y universal. No es de extrañar, entonces, que su público se encontrara en la minoría selecta de gusto cultivado, también citadina y arrogante. ${ }^{47}$

En términos personales, resultaba prácticamente imposible mantenerse al margen de las querellas. El año de 1909 fue decisivo en la vida de Alfonso Reyes: Porfirio Díaz dio el golpe final a don Bernardo Reyes, ordenándole que saliera del país. Interiorizado como estaba de los métodos del régimen, el general aceptó el destierro sin reproches, sometiéndose a las normas que él mismo había usado para con sus adversarios ${ }^{48} \mathrm{~A}$ partir de estos hechos, su hijo Alfonso se retrajo aún más del mundo político. En adelante, su obra literaria y su actitud frente a los acontecimientos nacionales se fundirían con la tragedia paterna, con el dolor ante la pérdida del hogar desmantelado ${ }^{49}$ y la añoranza por aquel México romántico de delicioso extranjerismo que comenzaba a disolverse.

\section{DÍAS ACIAGOS}

Sólo meses después de que José Vasconcelos se preguntara si su gene-

17 Quintanilla, "Ateneo", 1990, pp. 115-136.

18 Reyes, Oracion, 1963, pp. 9-24. 261.

${ }^{49}$ Henríquez Ureña, "Reyes", 1984, pp. 260- ración asistiría a "las épocas gloriosas en que los valores se rehacen",50 la respuesta fue dada: Madero huyó a San Antonio, Texas, y dio a conocer el Plan de San luis Potosí. La revolución había comenzado. "Lo que aconteció en México el año del Centenario -diría tiempo después Alfonso Reyes- fue como un disparo en el engañoso silencio del paisaje solar: todo el círculo de glaciales montañas se desplomó, y todas fueron cayendo una tras otra." 51

En sus inicios, el movimiento revolucionario se desarrolló en forma de ataques dispersos perpetrados en diferentes zonas del país. La intelectualidad urbana permaneció indiferente hacia estos sucesos. La experiencia de convulsiones sociales previas permitía suponer que la insurrección maderista sería derrotada y que pronto se restablecería el orden. Formados bajo el signo del "caudillo de la paz", cuya vida parecía eterna y su poder inamovible, los intelectuales no percibieron (quién podía hacerlo en aquel entonces) la magnitud de la tormenta que se avecinaba.

Por una u otra razón, los ateneístas adeptos a Madero no participaron en las sucesivas batallas que decidieron la renuncia de Díaz. Una vez firmados los acuerdos de paz, se integrarian al cuerpo administrativo aún en manos del aparato porfirista, renuente al cambio y dispuesto a mantener los antiguos privilegios. Así, los hombres de la revolución tuvieron que enfrentar tanto una vigorosa campaña con-

\footnotetext{
30 Vasconcelos, "Juventud", 1962, p. 112.

51 Reyes, "Pasado", 1967, pp. 162-163.
} 


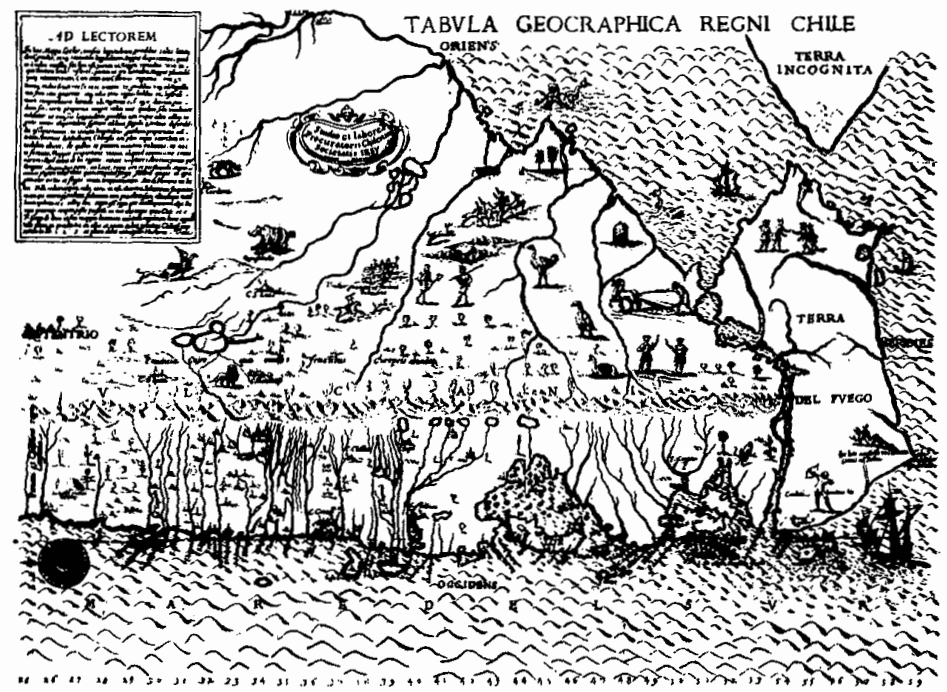

servadora en contra de todo cambio, como los golpes internos provocados por las divisiones dentro del bando revolucionario. Dichas disputas intestinas, fuente continua de "desilusión" y, a menudo, de reacomodos dentro de la administración pública, se agudizaron en la Convención Nacional Independiente. Alberto J. Pani, José Vasconcelos y Félix Palavicini permanecieron fieles a Madero, defendiendo la actitud negociadora, claudicante para algunos, del líder. ${ }^{52}$ Luis Cabrera, por el contrario, encabezó al bloque radical que exigía mayor vigor a la obra revolucionaria. 53

52 Pani, Contribucion, 1936, pp. 30-41; Vasconcelos, Ulises, 1983, vol. II, pp. 382-392.

53 Cabrera, Obras politicas, 1921, pp. 200213, 227-231, 273.
La presidencia de Madero no puso fin a los días aciagos vividos meses atrás. Las continuas rebeliones, la activa presencia de residuos porfirianos en el nuevo gobierno y la pérdida de su popularidad hacían más frágil aún a este régimen, escindido internamente e imposibilitado para reha. cer los daños de la guerra y para organizar debidamente una nueva administración. ${ }^{54}$ Las pugnas dentro del gobierno, sus conflictos y querellas, acentuaron las diferencias entre los ateneístas adeptos a la causa revolucionaria y aquellos que se mantenían fieles al poder central. Debido a sus enfrentamientos con Pino Suárez, Alberto $\mathrm{J}$. Pani tuvo que renunciar al

54 Cumberland, Madero, 1981, pp. 140-147. 
cargo de subsecretario de Instrucción Pública. 55 Durante su paso por el Congreso federal, Luis Cabrera exigió que se encarara con mayor firmeza a la oposición y se pusieran en marcha re. formas sociales, en particular las de carácter agrario. El conflicto en la Escuela de Jurisprudencia ${ }^{56}$ mostró a este "teórico de la revolución" la nece. sidad de utilizar la fuerza con los enemigos, así como la imposibilidad de lograr una transición concertada, sin cambios de orden social.

Las preocupaciones de José Vasconcelos eran de índole muy distinta a las de Cabrera. Su lealtad estaba con Madero, en quien reconocía al líder destinado a salvar al país de la destrucción. Pese a ello, no aceptó integrarse al gabinete: podía ganar más dinero ejerciendo como abogado. ${ }^{57}$ Esta decisión iba aparejada a un creciente recelo hacia los caudillos militares que, según su perspectiva, ponían en peligro la renovación espiritual por la que pasaba el país. La caída de la dictadura, escribiría tiempo despues, trajo de nuevo el antiguo conflicto de nuestra historia: "Oposición del troglodita y el idealista, perduración de la barbarie autóctona frente a los intentos regenerativos." 58

Los temores de José vasconcelos, su asombro ante la "barbarie" y su diatriba en contra de los líderes "oportunistas" que se sumaron a la revolución, son sintomáticos del sentir de aquellos intelectuales que, tras apoyar la causa

35 Pani, Contribución, 1936, pp. 100-109.

56 Martínez Suárez, "Escuela", 1955.

57 Según Taracena, Madero ofreció a Vasconcelos el cargo de subsecretario de Gobemación, pero éste no lo aceptó por temor a no entenderse con el ministro Manuel Calero.

58 Vasconcelos, Ulises, 1983, vol. II, p. 368. maderista, vieron con recelo el cariz inesperado que tomaba el conflicto en algunas regiones de la república. La división entre la ciudad y el campo, entre los ilustrados y el pueblo, afloró a raiz de los levantamientos populares en el norte y el centro del país. Que esto haya sido así no debe sorprendernos: imagine el lector lo que significó para una generación educada bajo la perspectiva, deseada o no, de un futuro apacible, el arribo desde la pro. vincia de un ímpetu renovador capaz de transformar aquello que, quizá con pesar, constituía su vida.

Con el triunfo de la revolución, acabaron temporalmente las esperanzas de los jóvenes reclutados por el partido científico. Dispersos, sin guías, repudiados por los grupos políticos emergentes, buscaron la forma de sobrevivir al naufragio mientras el panorama se aclaraba. Cuando esto sucedió, salieron de sus refugios para hacer blanco de sus ataques a un régimen que, justo es reconocerlo, toleró la crítica e incluso favoreció el ascenso de los opositores. Así lo muestra, por lo menos, el ejemplo de Nemesio García Naranjo, quien estuvo durante algún tiempo inactivo, sin vincularse a ninguna de las organizaciones que dominaban la escena pública. Tiempo después regresaría a la capital para ocupar una curul en el Congreso. Ahí, Nemesio formó parte (en compañía del también ateneísta José María Lozano) del famoso "cuadrilátero", voz renovada de un ayer vivo, actuante, que puso en jaque a la nueva administración. 59

39 García Naranjo, Memorias, 1963, vol. v, pp. 117-118, 155-234. 
Los ejemplos citados fueron casos excepcionales en un medio en el que privó la indiferencia y el desdén por los acontecimientos que asolaban al país. La mayor parte de los miembros del Ateneo permaneció como espectadora pasiva e incrédula de los sucesos revolucionarios. En su Diario, Alfonso Reyes dejó constancia del esfuerzo por continuar, entre tiroteos y motines, la labor intelectual, del temor ante la "porra" maderista que se había adueñado de la ciudad y de la nostalgia por la paz porfiriana que, pese a sus desventajas, ofrecía un clima propicio para la concentración personal y artística. ${ }^{60} \mathrm{La}$ imagen de su padre preso, consumiéndose en una celda, prefiguraba para él la "brutalidad", la "injusticia" y el "horror" del México revolucionario ${ }^{61}$ Los lazos con su patria estaban ya rotos; sólo lo mantenía en ella la solidaridad para con la familia y el general derrotado. Era una presencia silenciosa, encerrada en una atmósfera libresca, característica de una generación que haría de la soledad del escritor todo un mito.

En el campo intelectual, la impopularidad de Madero era alarmante. Los residuos de la intelectualidad porfirista, algunos entrañablemente unidos a la clictadura, concertaron una vigorosa campaña en contra de la obra revolucionaria. ${ }^{62}$ Aunque incómodos en un escenario que no les pertenecía, Antonio Caso, Pedro Henríquez Ureña

60 Reyes, Diario, 1969 , pp. 23-24.

61 Reyes, Oración, 1963 , pp. 9-24.

62 Los ateneístas Enrique González Martínez, Genaro Estrada, Nemesio García Naranjo, José María Lozano y Ricardo Gómez Robelo, participaron en esta campaña.
yJulio Torri no participaron en esta batalla periodística. El triunfo de la revolución venía a ser el resultado inevitable de la incapacidad del gobierno porfirista para adaptarse a su tiempo. Más que un reformador, un portavoz del futuro, Madero era para ellos una tuerca del engranaje conformado por un pueblo "bárbaro e inculto" y un gobierno gerontocrático $\mathrm{e}$ incompetente.

En junio de 1911, José Vasconcelos fue electo presidente del Ateneo de la Juventud, mismo que cambió su nombre por el de Ateneo de México. En su llamado para rehabilitar el "carácter de la raza", advirtió el peligro de que los políticos impusieran sus patrones sobre la tarea intelectual. La intelligentsia no podía ser gobernada, y menos aún por quienes carecieran de la madurez suficiente para dirigir. Los jóvenes habrian de acabar, afirmaba Vasconcelos en su discurso, con la mediocridad de la ciencia porfirista, pero sobre la base del respeto al conocimiento, la libertad de expresión y la autonomía con respecto al Estado. Lejos de intentar dirigir la cultura naciente, los políticos deberían cumplir los propósitos libertarios de la revolución e independizar al saber de la nutela estatal. 63 Como veremos, esta ilusión habría de derrumbarse en el transcurso del conflicto revolucionario.

El discurso de José Vasconcelos sintetizó las esperanzas de una comunidad que, desde tiempo atrás, había venido planteando la urgencia de espacios autónomos para el trabajo inte-

${ }^{63}$ Vasconcelos, "Gabino", 1962, p. 141. 
lectual, cansada de vivir en una sociedad en la que, en palabras de José Juan Tablada, "poesía y arte eran flores de invernadero" y "los artistas tan decorativos como los pájaros o las bandas de música". ${ }^{64}$ "Una vez que el Ypiranga zarpó con el notable pasajero, al fin pareció florecer en la capital la autonomía de esa comunidad, ya no como un agravio u ofensa, sino como algo por lo que había que enorgullecerse." 65 Este deseo de independencia explica, en parte, el énfasis puesto por algunos intelectuales del Ateneo en la autonomía universitaria, piedra de choque entre los universitarios y el gobierno.

En el transcurso del régimen maderista, y quizás estimulado por esa ola de renovación y cambio de principios de siglo, el grupo del Ateneo dio vida a la Universidad Popular Mexicana, última empresa común de los ateneístas. Estructurada como una institución laica, apolítica y no partidista, la Universidad Popular tenía como propósito fomentar la cultura del pueblo, en particular la de los gremios obreros. ${ }^{66}$ Su carácter independiente favoreció que intelectuales con pos-

64 José Juan Tablada, citado por Saborit, "Inercias", 1985, p. 185.

65 Saborit, ibid., pp. 185-186.

${ }^{66} \mathrm{La}$ iniciativa de fundar la Universidad Popular Mexicana surgió de los comentarios a que dio lugar la lectura del estudio de Alberto J. Pani sobre la instrucción rudimentaria en la república. Preocupados ante la necesidad de promover una "benéfica labor de extensión universitaria", los miembros del Ateneo designaron una comisión integrada por Alberto J. Pani, Alfonso Pruneda y Martín Luis Guzmán para elaborar el programa respectivo. Vease: Innes, "Universidad", 1973. turas políticas antagónicas participaran en las actividades promovidas por este organismo. Antonio Caso, quien se declaraba más porfirista que nunca, fue un entusiasta participante. Otro opositor a Madero, Enrique González Martínez, fungió como primer vicepresidente de la Universidad. También José María Lozano, entonces diputado y portavoz del ala conservadora, fue miembro de dicha institución. Sin embargo, la mayor parte de sus socios simpatizaba con el movimiento revolucionario.

\section{EL NAUFRAGIO}

En sus memorias, cartas y ensayos autobiográficos, los ateneístas describen los últimos días de Madero como un periodo de caos y confusión. Para aquellos que habían unido sus vidas a la del "Apóstol", fueron momentos de vileza, traiciones y también de debilidad, los cuales dejarían una huella indeleble en la historia del país. Para quienes simpatizaban con la contrarrevolución, fueron días decisivos, de esperanzas que pronto se derrumbarian por el conjuro de fuerzas "bárbaras", incontrolables, desatadas a partir de 1910.

Con el asesinato de Madero, la diáspora de los ateneístas comenzó a consumarse. Algunos optaron por el exilio; un exilio que habría de prolongarse y constituir toda una forma de vivir, también de morir, ${ }^{67}$ de mirar nuestro país y de acercarse a él. Tal fue el caso de Alfonso Reyes quien, tras re-

${ }^{67}$ Krauze, "Pasión", 1983, pp. 87-90. 
husarse a colaborar con Huerta, se fue a París. Salvo algunas excepciones, estuvo aislado de los mexicanos que, divididos por la contienda, huyeron a Europa. Su correspondencia con los $\operatorname{amigos}^{68}$ fue más un diálogo acerca de literatura que sobre los sucesos nacionales, en torno a los cuales evadía emitir su opinión. Quien leyese sus cartas sin cotejar orígenes y fechas, no podría saber que fueron escritas durante la revolución y en el centro de la primera guerra mundial. $Y$ es que Alfonso Reyes, nos dice su amigo Luis Cardoza y Aragón, vivió simpre fiel a la creencia de la liberación por la cultura; él prefería la injusticia al desorden y no conoció la gran virtud de la indignación. ${ }^{69}$

Para quienes -ya por temor, por lealtad o por convicción- se quedaron en México, habría de iniciarse una larga jornada llena de incertidumbres. Hubo quienes se integraron a las diversas fuerzas que, unidas por el propósito de destituir al "usurpador", confluyeron en el constitucionalismo. Conforme la lucha avanzaba, las grietas entre las varias facciones se hacian más profundas, poniendo a los intelectuales ante la necesidad de tomar partido por uno u otro bando. Martín Luis Guzmán se unió a Villa. Alberto J. Pani, Félix Palavicini, Alfonso Cravioto, José Vasconcelos y Luis Cabrera se pusieron a las órdenes de Carranza, nuevo líder de la revolución. Al salir de la ciudad de México, terreno peligroso para quienes no aceptaran la traición

68 Reyes/Nasconcelos, Ecrits, 1976; Reyes/ Henríquez Ureña, Correspondencia, 1986; Reyes/Torri, Epistolario, 1980, pp. 179-261.

69 Cardoza, Río; 1986. de Huerta, entraban a un campo resba. ladizo en el que el apoyo de los caudillos regionales era indispensable para sobrevivir.

Hasta entonces, nuestros protagonistas se habian movido en escenarios por ellos conocidos, bajo la férula de dirigentes con los que se sentían identificados. En adelante, tendrían que actuar en escenarios distintos a los suyos, dirigidos por líderes procedentes de un mundo distante, hostil. Alberto J. Pani tuvo que ganarse la simpatía de Carranza, ${ }^{70}$ quien recelaba de los viejos cuadros maderistas e imponía un rígido esquema de lealtades y tributos. Para otros, no quedó sino el camino del exilio, el alejamiento de una causa cada vez más desviada y alejada de sus metas originales o la "resistencia pasiva" en la ciudad de México. ${ }^{71}$ Desde Europa, donde fue enviado con la intrascendente misión de boicotear las finanzas de Huerta, José Vasconcelos, por ejemplo, vivía una segunda luna de miel con Adriana, combinando sus escasas actividades políticas con visitas a museos. ${ }^{72}$

La experiencia de Luis Cabrera fue muy distinta a la de sus antiguos condiscípulos del Ateneo. Tiempo atrás, desde la candidatura de Madero y Pino Suárez, había mostrado su inclinación por Carranza, con quien al paso del tiempo establecería una relación no acabada sino hasta la muerte del primero. En la figura del Primer Jefe se sintetizaban, para él, las cualidades que debian tener los conduc-

\footnotetext{
70 Pani, Contribucion, 1936, pp. 201-205.

71 Tal fue el caso del diputado Alfonso Cravioto.

72 Vasconcelos, Tormenta, 1978; pp. 21-42.
} 
tores del cambio que necesitaba el país. Como consejero y administrador, como teórico y hábil negociante, Cabrera sería una pieza clave en la maquinaria del carrancismo. ${ }^{73}$

Las reacciones, el sentir y el actuar de estos intelectuales, con todo y su autoadulación, oportunismo y charlatanería, contrastan con las de aquellos ateneístas que le hicieron caravanas al Usurpador y justificaron a la dictadura huertista. Con rapidez, quienes se quedaron en la capital aprenderían a guarecerse de los conflictos, buscar sustento en la burocracia y apoyo espiritual entre los amigos. Amparándose ya sea en una lógica de servicio altruista hacia un país que requería de sus "hombres más capaces" una pretendida ignorancia con respecto a los crímenes del huertismo, muchos integrantes del Ateneo desempeñaron cargos públicos. Jesús T. Acevedo era encargado de Correos; Julio Torri fue su secretario particular; Antonio Caso seguía su exitosa carrera académica, mientras Pedro Henríquez Ureña escalaba las jerarquías dentro de la universidad. Otros hacían cola en los ministerios para conseguir el ideal de todo joven intelectual de la época: un puesto en alguna embajada. Quienes habían sido leales defensores del antiguo régimen, obtuvieron su recompensa: José María Lozano fue nombrado secretario de Instrucción Pública y, más tarde, de Comunicaciones y Transportes. Ricardo Gómez Robelo ocupó el puesto de procurador

73 Beer, Luis, 1984, pp. 76-108; Meyer, Cabrera, 1972.

74 Véase, como ejemplo, la justificación de Genaro Fernández, Rio, 1969, p. 226. general de la nación. Nemesio García Naranjo sustituyó a Lozano en Instrucción Pública. 75

La colaboración de este sector del Ateneo con el gobierno huertista se debió a distintas razones, entre las que no habría de excluir la identificación de la intelectualidad urbana con el proyecto restauracionista. Asimismo, vivir como hombre de letras, mediante el comercio de sus productos culturales, era impensable en aquel entonces. Una de las pocas vías para sostenerse era la Universidad, pero el control del ejecutivo sobre la academia permitía excluir a los opositores. Por otro lado, con Huerta habían vuelto a sobresalir prestigiados universitarios, antiguos protectores del Ateneo y viejos conocidos. Todo indicaba que la contrarrevolución triunfaría y que sus enemigos, "militares improvisados", "campesinos guerrilleros" e "intelectuales mediocres", al decir de nuestros personajes, volverían a ocupar sus asientos de segunda en la vida nacional. Pese a sus debilidades, el huertismo era un terreno mucho más seguro y familiar que las "huestes" constitucionalistas, a las que se acusaba de amenazar la paz e imponer el caos.

Los vínculos entre el Presidente Indio y la intelligentsia que le sirvió fueron endebles y sostenidos por la conveniencia mutua. Para nadie eran desconocidas las limitaciones de Huerta, sus vicios e incapacidades. Los críme-

75 En sus cartas, Pedro Henríquez Ureña proporciono a Alfonso Reyes una detallada relación de las actividades políticas y culturales de sus amistades comunes durante el gobiemo de Huerta. Correspondencia, 1986, pp. 202-211, 239-262. 
nes comenzaron a pesar en la conciencia de algunos intelectuales, quienes, sin embargo, no se atrevieron a levantar la voz. La decisión del ejecutivo de militarizar a la Universidad escandalizó aun a quienes acostumbraban justificar los desaciertos del gabinete. ${ }^{76}$ Con el tiempo, quedó claro que el Beodo del Palacio acabaría por llevar a todos al precipicio. Sólo quedaba evitar que la caída fuese mortal.

Pese a las adversidades presentes y a aquellas que se avecinaban, la actividad académica y cultural del Ateneo siguió en pie. En 1914, y gracias a la iniciativa de Nemesio García Naranjo, la bandera del positivismo fue arriada de los recintos escolares. 77 Apoyados por el rector de la Universidad, Ezequiel A. Chávez, los ateneístas sobrevivientes tomaron por asalto la Escuela de Altos Estudios para poner en marcha la subsección de Literatura. ${ }^{78}$ La influencia que tendría este espacio orientado a profesionalizar $y$ ofrecer un sentido académico a la actividad literaria, queda demostrada por el hecho de que prácticamente todos los intelectuales de peso en la escena cultural posrevolucionaria pasaran por sus

76 García Naranjo, Memorias, 1963, vol. vII, pp. 287-292.

77 García Naranjo, Discurso, 1914.

78 El rector de la Universidad, Ezequiel A. Chávez, además de conseguir una ampliación de los recursos, puntualizó los objetivos de la Escuela de Altos Estudios y la dotó de programa y cuerpo docente estables. En su primera etapa, la reforma fomento el desarrollo de cursos destinados a formar profesores en el área de lengua nacional y literatura. A mediados de 1913, la subsección se encontraba en plena actividad, con trece profesores a la cabeza. Boletin de Instrucción Pública (3 y 4) (mar.-abr. 1913); Henríquez Ureña, "Cultura", 1962. aulas. Ahí estudiaron los "Castros", algunos miembros de la generación del 15 y uno que otro "contemporáneo".79

La actividad cultural desplegada por los sobrevivientes del Ateneo rebasaba, con mucho, los salones de clase. Empeñados en mantener el saber dentro de un mundo dominado por la bala, estos intelectuales desarrollaron una tenaz labor de difusión y docencia que contaba con un público ávido, sin posibilidad de mirar al exterior. Para las nuevas generaciones, los ateneístas eran sus únicas ventanas hacia la alta cultura, entendida ésta como "el cultivo de una sensibilidad capaz de conmoverse ante las obras maestras del hombre". ${ }^{80}$ El legado del Ateneo, afirmó Vicente Lombardo Toledano-quien por entonces era un adolescente recién llegado a la capitalmarcó a su generación, la del 15, y desató en muchos de sus miembros la vocación literaria, la inquietud por las cuestiones filosóficas y el interés hacia la cultura universal. ${ }^{81}$

Ya para 1914, el sueño de una sofocracia había sido derrumbado. El ejército constitucionalista se acercaba a la ciudad; el Ateneo de México daba sus últimos soplos de vida. Conforme el gobierno de Huerta caía, se acrecentaban las pugnas entre sus colaboradores. Los chismes y las intrigas comenzaron a hacer estragos entre las filas intelectuales. A mediados del año, Pedro Henríquez Ureña salió de México,

79 Álvarez, Vida, 1962, pp. 159-164; Cosío Villegas, Memorias, 1976, pp. 40-42, 46-50; Garrido, Tiempo, 1974, pp. 47-53, 67-68; Krauze, Caudillos, 1976, pp. 57-66.

80 Cosío Villegas, Memorias, 1976 , p. 56.

81 Toledano, "Henriquez Ureña", 1962. 
rumbo a La Habana. Más tarde, confe. saría a Alfonso Reyes que la ciudad era entonces un "infierno" y que Huerta era el "más estúpido e infame gobernante de la historia de América" ${ }^{82}$ En una carta enviada al mismo destinatario, Antonio Caso describió así su sentir de aquel momento:

Devoción sin entusiasmo, esfuerzos y esfuerzos y esfuerzos sin premio, eso es lo que ha de formar nuestra divisa principalmente en los días aciagos de batalla y crímenes. El mexicano culto es una de las inadaptaciones incuestionables del mundo: iqué remedio: ${ }^{83}$

82 Reyes/Henríquez Ureña, Correspondencia, 1986, p. 299. p. 74 .

\section{LA DIÁSPORA}

El día 20 de agosto de 1914, Carranza entró a la ciudad de México, flanqueado por algunos de los más conocidos líderes militares del país. Previamente a su arribo, la prensa había difundido alarmantes noticias sobre el "bárbaro" comportamiento del ejército constitucionalista. Atemorizados, los miembros del Ateneo que simpatizaban con los conservadores, esperaron la invasión de los Atilas que vendrían a "destruir los hogares", sembrar la "ley del gatillo" y fusilar a los colaboradores del Usurpador. Hasta entonces, la revolución era, para ellos, un suceso lejano; en adelante, sería un hecho tangible que vino a acabar, en palabras de Genaro Fernández Mac-

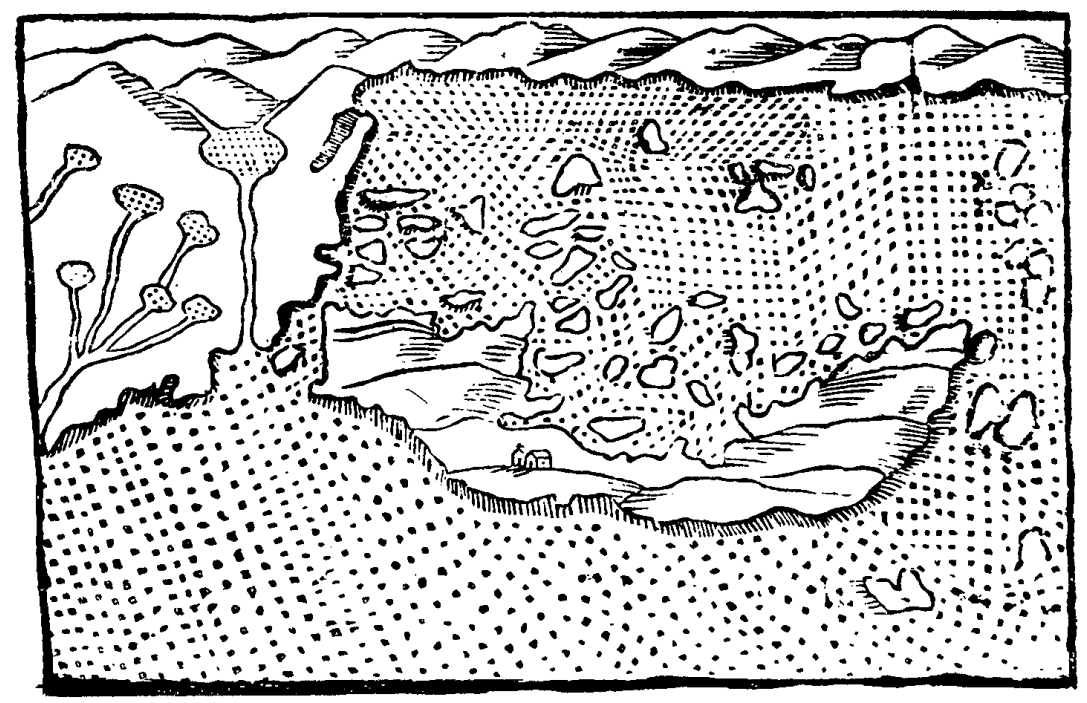


Gregor, con el sueño de un México culto y civilizado:

Las tropas carrancistas entraron a la ciudad a mediados de agosto. La curiosidad lanzó a la calle al populacho. Los individuos de la clase media nos quedamos en nuestros domicilios. De pronto, en la calle, ruidos de caballerías. Suspendemos la lectura y nos asomamos a la ventana. Entraban a México... Los dragones de Lucio Blanco: hombres de clase proletaria, campesinos atezados, vestidos abigarradamente los unos, y los casi sin vestir, pero eso sí cruzados los pechos y las cinturas por triples cananas $[. .$.$] Los contemplábamos en si-$ lencio, rumiando pensamientos amargos. Nuestros sueños de un México culto habian sido vanos. Eso que desfilaba ante nuestros ojos era México, el verdadero en toda su terrible realidad, el que demandaba justicia, educación y pan $[. .$.$] Desde aquel día fue también en$ nuestras mentes inolvidable, indeleble, la tragedia de nuestra patria. ${ }^{84}$

Quienes participaron activamente en el régimen derrotado no aguardaron a ver qué castigos les deparaba el bando vencedor. En cuanto Huerta envió su dimisión al Congreso, Nemesio García Naranjo se embarcó en el Buenos Aires; en el mismo buque iban los ateneístas José María Lozano, Ricardo Gómez Robelo, Jesús T. Acevedo e Ignacio Bravo Betancourt. ${ }^{85}$ Antonio Caso, Julio Torri, Mariano Silva y Aceves, Carlos Díaz Dufóo, Jr. y Genaro Fernández MacGregor, menos comprometidos con la causa contrarrevo-

84 Fernández MacGregor, Rto, 1969, p. 243.

85 García Naranjo, Memorias, 1963, vol. VII, pp. 368-369. lucionaria, permanecieron en la ciudad de México.

A pesar de que desde la victoria del constitucionalismo era evidente el enfrentamiento con Villa y Zapata, Carranza organizó de inmediato su cuerpo administrativo. El nuevo ministro de Instrucción Pública, Félix Palavicini, procedió a despedir a todo el personal que trabajaba en esa dependencia y a correr a muchos maestros y a sustituir a las autoridades de las escuelas superiores. Los puestos vacantes les fueron concedidos a los "hom. bres de la revolución", entre ellos varios ateneístas: Alfonso Cravioto (jefe de la sección universitaria), José Vasconcelos (director de la Escuela Nacional Preparatoria) y Alfonso L. Herrera (director del Museo de Historia Na. tural). Habría que agregar a esta lista los nombres de Jesús Urueta, Alberto J. Pani, Luis Cabrera e Isidro Fabela, todos ellos funcionarios del régimen triunfante.

El choque entre estos nuevos dirigentes y aquellos intelectuales que habían mantenido en pie la vida aca. démica durante el huertismo resultaba inevitable. En septiembre de 1914, Félix Palavicini encomendó a Valentín Gama la elaboración de un proyecto de ley para declarar la autonomía de la Universidad Nacional. ${ }^{86}$ La propuesta fue discutida en el Consejo Universitario los días 27 y 30 de octubre de ese año. ${ }^{87}$ Más tarde, Alfonso Cravioto -por entonces director de Bellas Artesy Jesús Natividad Macías presenta-

86 Palavicini, "Discurso", 1914, pp. 19-21.

87 Las actas de estas reuniones se encuentran en el archivo del CESU, Fondo Consejo Universitario, caja 6, exp. 4. 
ron una nueva iniciativa legal en la que se sostenía la necesidad de que la Universidad permaneciera ajena a "las fluctuaciones de la política, inde. pendiente del poder público y libre de toda intervención oficial, sin las limitaciones, la esclavitud burocrática y la tutela ministerial con que fue establecida en $1910 "{ }^{88}$ Dado que las actividades universitarias estaban destinadas a satisfacer a una minoría selecta con recursos para sufragar el costo de los estudios, se pensó suprimir el pago del personal docente y formar un cuerpo de profesores sujeto a las leyes de oferta y demanda.

Para el grupo identificado con Carranza la autonomía era, más que un imperativo de orden académico, un paso indispensable en la perspectiva de suprimir la Secretaría de Instrucción, liberar al gobierno federal de una carga financiera considerada como superflua y modificar la tendencia "reaccionaria y oportunista" de los académicos. ${ }^{89}$ Entre las autoridades de la universidad privaba una concepción distinta que anteponía la facultad de autogobierno y el saber neutral por encima de los conflictos y los menesteres sociales. El poder público tenía el deber de subsidiar a la universidad, mas no el derecho de administrarla;

${ }^{88}$ Boletin de Educación (3) (2), pp. 19-21.

89 En el mencionado proyecto de ley se decía que la independencia administrativa del personal docente... "había rebajado el nivel intelectual de los estudiantes de México y deprimido su nivel moral en tal forma que durante los últimos ańos los escolares de la capital y de la cepública, antes liberal, se han convertido en una clase reaccionaria y acomodaticia, donde todo entusiasmo ha muerto y todo ideal se ha extinguido". Ibid, p. 21 . de quedar supeditada a los vaivenes políticos, ésta perdería la fuerza que emana de la libertad intelectual. ${ }^{90}$

La discusión en torno a la autonomía universitaria fue temporalmente suspendida con la partida de Carranza y su gabinete hacia Veracruz. Sin embargo, maestros y estudiantes persistieron en su esfuerzo por liberar a la universidad de la férula del Estado. En diciembre de 1914, cuando Eulalio Gutiérrez recibía de manos de Eufemio Zapata la residencia oficial, un grupo de universitarios (entre los que sobresalen los ateneístas Antonio Caso y Luis G. Urbina) elaboraron un nuevo proyecto de ley en el que se decretaba la independencia de esta institución y se proponían mecanismos autogestivos para la elección de autoridades. ${ }^{91}$ Si bien este desesperado esfuerzo no prosperó, la aspiración de independizar a la academia se mantendría viva.

Una vez fracturada la coalición de los ejércitos opositores a Huerta, los intelectuales que habían participado en la lucha (y muchos más que salieron de sus guaridas para engrandecerse bajo la sombra de los jefes militares) tuvieron que tomar partido entre uno u otro bando. La mayor parte optó por seguir a Carranza, quien ya para entonces había logrado atraer la simpatía de un sector representativo de la intelectualidad; de una intelectualidad acostumbrada a señalar las carencias de los caudillos populares, en

90 En su tesis para obtener el título de abogado, Pedro Henriquez Ureña hace una lúcida defensa de esta posición. Henríquez Ureña, Universidad, 1969 , pp. 45-70 .

91 Appendini, Historia, 1976 , pp. $81-82$. 
particular de los de origen campesino, a hacer mofa de su falta de instrucción, modales e ineptitud.

Puesta ante el dilema de elegir entre Zapata o Carranza, la intelligentsia del Ateneo se volcó hacia este último, quien leía a los clásicos griegos en medio de las gestas bélicas. A diferencia de sus enemigos, dice en sus memorias Alberto J. Pani, Carranza era un hombre "decente", "sensato" y "capaz".92 Una caracterización similar encontramos en la biografía de Félix Palavicini, quien vio en Carranza una mayor "capacidad de patriotismo y de decencia" que en sus antiguos aliados. Este mismo autor no recela en acusar a los ejércitos de la Convención de haber cometido "pavorosos crímenes" y pillerías en la ciudad de México, de haber matado sólo por capricho. Quizás con la intención de contrastar el "buen comportamiento" de los constitucionalistas con la "barbarie" de sus enemigos, destaca el hecho de que en Veracruz no abundaran las "mujeres ale. gres" que solían seguir a las fuerzas militares, ni se dieran casos de abuso o "licencia sexual". 93

La inclinación de esta pléyade intelectual hacia la causa constitucionalista no puede atribuirse sólo a la identidad de "clase" entre la minoría ilustrada y el proyecto de $\mathrm{Ca}$ rranza, mismo que ha sido reiteradamente caracterizado como de carácter "burgués". Tampoco es válido acusar de "traición", "oportunismo" o "vileza" a quienes tomaron la vía abierta por

92 Pani, Contribucion, 1936, p. 208.

93 Palavicini, Vida, 1937, pp. 223-224, 227. 229. el constitucionalismo en contra de los ejércitos leales a la Convención. Las desemejanzas programáticas entre ambas fuerzas no eran tan profundas ni insalvables como suponen quienes acostumbran poner etiquetas clasistas al proceso revolucionario (burguesa para Carranza, popular para la Convención). Existían, eso sí, diferencias en cuanto a los orígenes, la dinámica interna, la composición, las estrategias de lucha y la "cultura política" de una $y$ otra fracción. ${ }^{94}$ Estas diferencias, y no supuestos "instintos de clase", explican el porqué, por citar sólo un ejemplo, Luis Cabrera (quien, como vimos, venía defendiendo desde tiempo atrás la urgencia del reparto agrario) se alió a Carranza. José Vasconcelos, a quien nadie se atrevería a calificar de radical, formó parte de la Convención, misma que atrajo a muchos ex maderistas en nada identificados con el movimiento campesino que constituía la base de los ejércitos convencionistas.

La dinámica que por entonces cobraba el proceso revolucionario modificó sensiblemente la función del intelectual. Del biógrafo, artista ornamental o, en todo caso, consejero de banquillo, se transitó hacia el reformador social. Impulsados por una realidad que exigía pronta solución a los problemas laborales, educativos y agrarios, los intelectuales carrancistas actuaron como ideólogos de una fuerza que, en el transcurso de la batalla, fue haciéndose de un proyecto nacional. Las reformas sociales habían surgido de la reserva y comenzaban a ser blandidas como armas de lucha, tan o más

94 Knight, "Peasant", 1980. 
importantes que las de fuego. ${ }^{95}$ Por órdenes de Carranza, fue creada en Veracruz la Sección de Legislación Social, organismo encargado de "realizar las transformaciones que la revolución mexicana exigía", procediendo al estudio y la expedición de las leyes proteccionistas. ${ }^{96}$ Muchos de estos proyectos, parcialmente aplicados durante la guerra, pasarian a formar parte de la Constitución del 1917.

$\mathrm{La}$ experiencia de los escasos ateneístas aliados a la Convención fue muy diferente a la de sus antiguos condiscípulos. Como se sabe, Villa y Zapata fueron mucho más refractarios que los dirigentes constitucionalistas al control de los intelectuales externos, tenían mayor renuencia a dejar la administración en manos de los "catrines" y eran poco afec. tos a seguir los esquemas de "decencia" y "moralidad" de sus ilustres consejeros. ${ }^{97}$ Estos últimos tuvieron su mejor momento durante la primera etapa de la Convención de Aguascalientes, cuando surgió la posibilidad, pronto clausurada, de constituir un gobierno civil -para algunos "civilizado"- por encima de los jefes militares. El tiempo, sin embargo, habría de mostrar lo irrealizable de esta pretensión.

En La tormenta, José Vasconcelos describe sus avatares de aquellos años. Se trata de una narración parcial, poco fidedigna. Pero, más allá de su falta de objetividad, el texto transmite la percepción de su protagonista ante los

95 Córdova, Ideologia, 1973, p. 194.

96 Palavicini, Vida, 1937, pp. 234-241.

97 Katz, "Intelectuales", 1991, p. 6. acontecimientos de la época, la impotencia del ejecutivo frente a la "barbarie" de las masas, el miedo ante el "México bronco" y el desprecio hacia los caudillos, en cuyas manos estaba el destino del país. Atrapado en el torrente de divisiones $e$ intrigas, que comenzaba a desbordarse de las filas convencionistas, Vasconcelos rompió definitivamente con sus "incultos" aliados. En su ánimo, la revolución entera se había convertido, gracias a los "rufianes" del nuevo ejército, en una matanza entre "caníbales". Derrotado el proyecto maderista, la gesta revolucionaria no era sino una "contienda entre matones". 98

Una de las primeras, y únicas, ac. ciones de José Vasconcelos durante su infortunada gestión como ministro de Instrucción Pública fue nombrar a Antonio Caso director de la Escuela Nacional Preparatoria. Para entonces, Caso era el bastión de la cultura humanista en la metrópoli, así como el líder de un movimiento cultural que surgió en medio de la devastación producida por la contienda. Por un lado, estaba el espectáculo de los soldados pidiendo limosna, de los salones de baile convertidos en caballerizas, de las lujosas casas ocupadas por la soldadesca. Por el otro, la imagen de Europa sumida en llamas. En este escenario "dantesco", florecieron formas particulares de ver al pais, de apropiarse de su historia y de vislumbrar el futuro. La de Caso fue una visión apocalíptica, salpicada de prédicas. Su doctrina, punto de referencia inevitable para las nuevas generaciones, impugnaba por

98 Vasconcelos, Tormenta, 1978. 


\section{Ysla de Santa' Muria}

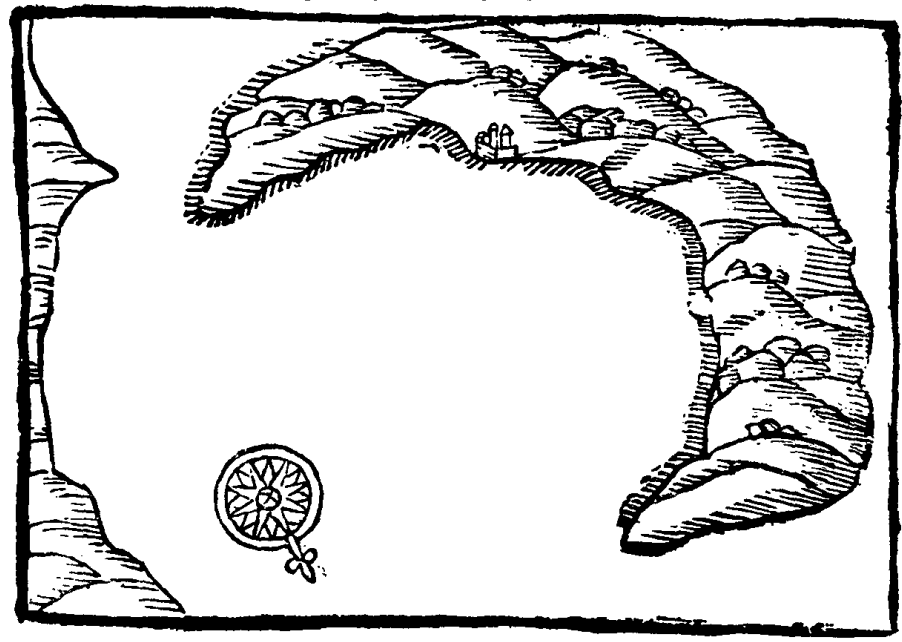

igual al individualismo que al pensamiento racionalista en nombre de los valores éticos, la armonía y el dogma cristiano. Otro sobreviviente a los fusilamientos, Julio Torri, sorteaba con humor las batallas cotidianas en una ciudad en la que, pese a todo, aún se podían satisfacer "gustos paganos": la amistad, el juego, el amor, los libros y el placer de escribir. ${ }^{99}$

Lejos del país, en aquellos lugares a donde habían ido a parar los cada vez más numerosos exilados, se produjo una cultura en el exilio, un movimiento de crítica y desesperanza, de rechazo y a la vez compulsiva atracción hacia la épica revolucionaria. Villistas arrepentidos, uno que otro residuo de los "científicos", ex maderis-

99 Reyes/Torri, Epistolario, 1980. tas e independientes, unieron sus voces para denunciar el camino "sangriento y bárbaro" que tomaba la revolución. En 1915, en España, Martín Luis Guzmán publicó La querella de México, ${ }^{100}$ ensayo pesimista que prefiguraba toda una etapa en la producción literaria y política del Ateneo. Por ese tiempo, Nemesio García Naranjo dirigía la publicación de la $R e$ vista Mexicana, espacio editorial que sirvió, en palabras de su director, para "vaciar el desahogo patriótico que no conducía a resultado práctico alguno [...] pero que dejaba echar el fuego que los desterrados tenían dentro". ${ }^{101}$

Eran tiempos de desdicha y de

100 Guzman, Querella, 1915.

101 García Naranjo, Memorias, 1963, vol. vil, p. 79 . 
amargura, también de miseria. Errante, cada vez más crítico hacia las "tribus de caníbales" que dominaban al país, José Vasconcelos redobló su pasión por la filosofia. En su vagabundeo de aquellos años, comenzó la alegoría del intelectual mexicano, y de él mismo, como un nuevo Ulises que, amparado por Minerva, compite contra guerreros y mantiene despierto, con sus viajes y penas, el espíritu nacional. ${ }^{102}$ Lejos de su patria, en un exilio que pasó a ser voluntario, Alfonso Reyes hilvanaba, entre retazos y evocaciones, su discurso sobre la labor intelectual, la función del artesano escriba, del escritor. Opuso a las teorías de la aceptación, del misticismo pasivo y del miedo al cambio, sus conjeturas en torno a la rebeldía, la acción, la libertad y la duda. Ubicado en el punto intermedio entre el conformismo que "invita a instalarse cómodamente en la vida para dormir la fiesta filosófica", $y$ el activismo rebelde que incita "a arrojarse a la calle por el balcón", Alfonso Reyes reivindicó un estilo, una forma de ser, de actuar y de vivir, de dedicarse al "juego ocioso" de la inteligencia. ${ }^{103}$

Para 1916, cuando el triunfo constitucionalista era evidente, la división de la pléyade del Ateneo en dos fracciones por el momento irreconciliables ya se había producido. En un lado estaban aquellos intelectuales del constitucionalismo que, pese a sus diferencias, vivían momentos de entusiasmo con respecto a la obra revolucionaria, a sus líderes y a sus resultados. Por el

102 Vasconcelos, "Juventud", 1962.

103 Reyes, El suicida, 1954. otro, aquellos que habian unido sus destinos a las distintas fuerzas derrotadas o tomado, desde tiempo atrás, el camino de la "pluma" y no el de la "pala". Los primeros se dieron a las tareas de elaborar proyectos, dirigir la labor de reconstrucción y glorificar la figura de los caudillos; los segundos pasaron por lo que, años más tarde, definirían como una de las etapas más amargas de sus vidas. La suerte, sin embargo, no estaba echada: la fortuna daría aún más vueltas para encumbrar a los vencidos y hacer de los héroes momentáneos las víctimas del futuro.

Independientemente del mando al que se sirviera, los intelectuales del Ateneo vivieron durante esos años una experiencia común: el depender y saberse dirigidos por aquellos que no poseían títulos ni saberes, es decir por caudillos militares "corruptos e incompetentes". Los acontecimientos posteriores al golpe de Huerta hicieron tangible que el futuro del hombre de ideas, su posibilidad de ejercer influencia y desplegar sus proyectos, dependería de sus vínculos con el Estado; unos vínculos corporativos, de lealtades, tributos y tensiones, que dejaban pocos espacios para la autonomía y la crítica intelectual. En el transcurso de la lucha armada, se tejieron nuevos lazos entre la cultura y el poder. Las cartas estaban echadas. En adelante, los protagonistas del conflicto tendrían que respetar las reglas y asumir los límites del poder intelectual.

\section{BIBLIOGRAFÍA}

-Alvarado, María de Lourdes, "La Escuela 
de Altos Estudios. Sus orígenes", Memoria del Primer Encuentro de Historia sobre la Universidad, Universidad Nacional Autónoma de México/Centro de Estudios sobre la Universidad, México, 1984.

-Appendini, Guadalupe, Historia de la Universidad Nacional de México, Porrúa, México, 1976.

-Beer, Gabriella de, Luis Cabrera: un intelectual en la Revolución Mexicana, Fondo de Cultura Económica, México, 1984.

-Blanco, José Joaquín, Se llamaba Vasconcelos, Fondo de Cultura Económica, México, 1977.

-Brunner, J. y A. Flisfisch, Los intelectuales y las instituciones de la cultura, Flacso, Santiago de Chile, 1981.

-Cabrem, Luis, Obras politicas de Blas Urrea: recopilación de escritos publicados durante los años 1909, 1910, 1911 y 1912..., Imprenta Nacional, México, 1921. -Calderón Vega, Luis, Los siete sabios de México, Editorial Jus, México, 1961.

-Camp, Roderic Ai, Los intelectuales y el Estado en el México del siglo XX, Fondo de Cultura Económica, México, 1988.

- Carballo, Emanuel, Diecinueve protagonistas de la literatura mexicana del siglo XX, Empresas Editoriales, México, 1965. -Careaga, Gabriel, Los intelectuales $y$ la política en México, Extemporáneos, México, 1971.

-Cardoza y Aragón, Luis, El río, Fondo dé Cultura Económica, México, 1986.

-Cockcroft, James, Precursores intelectuales de la Revolución Mexicana, Siglo XXI Editores, México, 1976.

-Córdova, Amaldo, La ideología de la Revolución Mexicana, Eraんnam, México, 1973.

-Cosío Villegas, Daniel, Memorias, Joaquín Mortiz, México, 1976.

_ _ "De cómo la revolución empezó con tinta", en Gabriel Zaid (comp.), Imprenta y vida pública, Fondo de Cultura Económica, México, 1985, pp. 123 . 143
"El intelectual mexicano y la política", en Zaid, Imprenta, 1985, pp. 6787.

-Cumberland, Charles, La Revolución Mexicana. Los años constitucionalistas, Fondo de Cultura Económica, México, 1972.

- Madero y la Revolución Mexicana, 2a ed., Siglo XXI Editores, México, 1981.

-Farias, Héctor, Nemesio Garcia Na. ranjo: Mexico's Minister of Education, 1913-1914, Graduate School Northwestem University, Evanston, 1971.

-Fernández Mac Gregor, Genaro, "El Ateneo de la Juventud", Boletín Bibliográfico de la Secretaría de Hacienda y Crédito Público, noviembre 1960.

, El río de mi sangre, Fondo de Cultura Económica, México, 1969.

-Franco, Jean, La cultura moderna en América Latina, Grijalbo, México, 1983.

-Gamboa, Federico, Diario (1892-1939), selección y notas de José Emilio Pacheco, Siglo XXI Editores, México, 1977.

- García Naranjo, Nemesio, Discursos pronunciados por.. en las aperturas de los cursos universitarios y de la Escuela Nacional Preparatoria los días 4 y 16 de febrero de 1914, Imprenta del Museo de Arqueología, México, 1914.

co, 1963. , Memorias, 9 vols., s.e. Méxi-

-Garrido, Felipe, José Vasconcelos: de su vida y de su obra, UNAM, México, 1982.

-Gaxiola, Francisco Javier, Memorias, Porrúa, México, 1975.

-Goldsmith, Bemard, The Ateneo de la Juventud, Clark University, 1969.

-Gómez Morín, Manuel, 1915 y otros ensayos, Editorial Cvltvra, México, 1927. -Gómez Quiñones, Juan, Porfirio Diaz, los intelectuales y la revolución, El Caba. llito, México, 1982.

-González y González, Luis, Todo es bistoria, Cal y Arena, México, 1989.

-González Ramírez, Manuel, Recuerdos 
de un preparatoriano de siempre, UNAM, México, 1982.

-Granados Chapa, Miguel Ángel, Al. fonso Cravioto: biografia de un intelectual bidalguense, Océano, México, 1984.

-Guerra, François Xavier, México: del antiguo régimen a la revoluctón, 2 vols. Fondo de Cultura Económica, México, 1988.

"Teoría y método en el análisis de la revolución mexicana", Revista $M e$ xicana de Sociología, vol. LI, núm. 2, abriljunio 1989, pp. 3-24.

-Guevara Niebla, Gilberto, "La autonomía universitaria en el proyecto de Justo Sierra", Siempre!, suplemento La cultura en México, núm. 138, 26 diciembre 1979.

-_ Las luchas estudiantiles en México, 2 vols., Línea, México, 1983.

Guzmán, Martín Luis, La querella de México, Imprenta Clásica Española, Madrid, 1915.

-Henríquez Ureña, Pedro, Universidad yeducación, UNAM, México, 1969.

-.__ Estudios Mexicanos, Fondo de Cultura Económica, México, 1984.

_ _ "La cultura de las humanidades", en Hernández Luna (comp.), Conferenctas, 1962.

-Hernández Luna, Juan, "Sobre la fundación de la Universidad Nacional", Historia Mexicana, vol. xvil, (1), enero-marzo 1967.

..._. Las conferencias del Ateneo de la Juventud, UNAM, México, 1962.

-Innes, John, "The Universidad Popular Mexicana", The Americas, vol. xxx, julio 1973, pp. 110-122.

-Katz, Friederich, "Pancho Villa y la revolución mexicana", Revista Mexicana de Sociología, vol. LI, núm. 2, 1989, pp. 87. 114.

_, "Los intelectuales de la revolución mexicana", Nexos, núm. 163, 1991, pp. 5-8.

-Knight, Alan, "Peasant and caudillo in the mexican revolution", en David Bra- ding, Caudillo and peasant in the Me. xican Revolution, Cambridge University Press, Cambridge, 1980.

- , "La revolución mexicana: eburguesía nacionalista, o simplemente una 'gran rebelión?'", Cuadernos Políticos, núm. 48, octubre-diciembre 1986, pp. 533.

$\longrightarrow$, "Los intelectuales en la revolución mexicana", Revista Mexicana de Sociología, vol. LI, núm. 2, abril-junio 1989 , pp. 25-67.

-Krauze, Enrique, Caudillos culturales en la Revolución Mexicana, Siglo XXI Editores, México, 1976.

- , "Pasión y contemplación en Vasconcelos", Vuelta, núms. 78-79, mayojunio 1983, pp. 16-26, 12-19.

, "El caudillo Vasconcelos", en José Vasconcelos, de su vida y' su obra, UNAM, México, 1984, pp. 25-49.

Joaquín Mortiz, México, 1990.

-Lombardo Toledano, Vicente, "El sentido humanista de la revolución mexicana", en Hernández Luna (comp.), Conferencias, 1962.

- "Pedro Henriquez Ureña, el educador", Stemprel, núm. 224, junio 1966.

-Martínez, José Luis (ed.), Alfonso Reyes/Pedro Henriquez Ureña: Correspondencia, Fondo de Cultura Económica, México, 1989.

-Meyer, Eugenia, Luts Cabrera: teórico y crítico de la Revolución, SEP, México, 1972.

-Monsiváis, Carlos, "Textos y pretextos. La fabricación de la nostalgia", El Universal, 14 marzo 1967.

, "Porfirismo y revolución. Los destinos legendarios y la promoción cultural", Siempref, suplemento La Cultura en México, núm. 120, agosto 1975.

, "Notas sobre la cultura mexicana del siglo XX", en Historia general de México, t. Iv, El Colegio de México, México, 1976, pp. 318-357. 
__ - "La aparición del subsuelo. Sobre la cultura de la revolución mexicana", Historias, núms. 8-9, enero-junio 1985.

-Murillo Reveles, Antonio, "La Universidad Nacional Autónoma y la revolución mexicana, Boletín Bibliográfico, abril 1961.

-O'Gorman, Edmundo, "Justo Sierra y los orígenes de la Universidad de México", Filosofía y Letras, vol. XVII, núm. 33, eneromarzo 1948.

-Palavicini, Félix, Mi vida revolucionaria, Botas, México, 1937.

, "Discurso pronunciado en la inaguración de los cursos universitarios", Boletín de Educación, vol. III, núm. 2, 1914.

-Pani, Alberto J., Mi contribución al nuevo régimen, 1910-1933, Cvltvra, México, 1936.

-Pasquel, Leonardo, "Juventud del maestro Antonio Caso", Hoy, 27 agosto 1955.

-Quintanilla, Susana, "El Ateneo de la Juventud: trayectoria de una generación", tesis doctoral, UNAM, México, 1990.

__ _, "La formación de los intelectuales del Ateneo: un estudio de casos" (en prensa).

-Raat, William, "Ideas and society in don Porfirio's Mexica", The Americas, vol. $\mathrm{xxx}$, núm. 1, julio 1973, pp. 32-53.

_., "The antipositivist movement in prerevolutionary Mexico. 1892-1911", Journal of Interamerican Studies and World Affairs, vol. XIX, núm. 1, febrero 1977, pp. 83-98.

-Reyes, Alfonso, "Nosotros", Nosotros, marzo 1914, pp. 216-221.

México, 1963.

, Oración del 9 de febrero, Era, -, "Pasado inmediato", Universidad, politica y pueblo, pp. 123-169.

_ - Diario (1911-1930), Universidad Autónoma de Guanajuato, Guanajuato, 1969.

, Nasconcelos, Ecrits oubliés.
Correspondance entre José Vasconcelos et Alfonso Reyes, Claude Fell (ed.), Instituto Francés de América Latina, México, 1976.

-Reyes, Alicia, Genio y figura de Alfonso Reyes, EudEBA, Buenos Aires, 1976.

-Ruiz Gaytán, Beatriz, "Justo Sierra y la Escuela de Altos Estudios", Historia Mexicana, vol. XVI, núm. 1, abril-junio 1970, pp. 541-564.

-Saborit, Antonio, "Las inercias culturales", Historias, núms. 8-9, enero-junio 1985, pp. 179-189.

-Schmidt, Carl, "Los intelectuales de la revolución desde otra perspectiva", $R e$ vista Mexicana de Sociologia, vol. I, núm. 1, abril-junio 1982 , pp. 27-87.

-Skirius, John, "Vasconcelos: el político y el educador", en José Vasconcelos, de su viday su obra, UNAM, México, 1984, pp. 5080.

-Steiner, George, En el Castillo de Barba Azul, Gedisa, Barcelona, 1991.

-Tannenbaum, Frank, Peace by revolution: an interpretation of Mexico, Nueva York, 1933.

-Torres Bodet, Jaime, Memorias, 2a. ed, Porrúa, México, 1981.

-Torri, Julio, "Epistolario: Julio TorriAlfonso Reyes", Diálogo de los libros, 1980, pp. 179-261.

-Uría Santos, Ma. Rosa, "El Ateneo de la Juventud: su influencia en la vida intelectual de México", tesis doctoral, Universidad de Florida.

-Vasconcelos, José, "Don Gabino Barreda y las ideas contemporáneas", en Hernández luna (comp.), Conferenctas, 1962, pp. 97-113.

, "El movimiento intelectual contemporáneo de México", en Hernández Luna (comp.), Conferencias, 1962, pp. 118-134.

, "La juventud intelectual mexicana y el actual momento histórico de nuestro país", en Hernández Luna (comp.), Conferencias, 1962, pp. 135-138. 
1978.

1983.

-Vaughan, Mary, "Primary education and literacy in Mexico in the nineteenth century: research trends: 1968-1988", ponencia presentada en el Simposio sobre Historiografía Mexicanista, Oaxtepec, 19681988.
-Vázquez, Josefina, Nacionalismo y educación en México, El Colegio de México, México, 1970.

-Villegas Moreno, Gloria, "La Universidad de Justo Sierra y la Revolución", Memoria del Primer Encuentro de Historia sobre la Universidad, UNAM/CEU, México, 1984. 


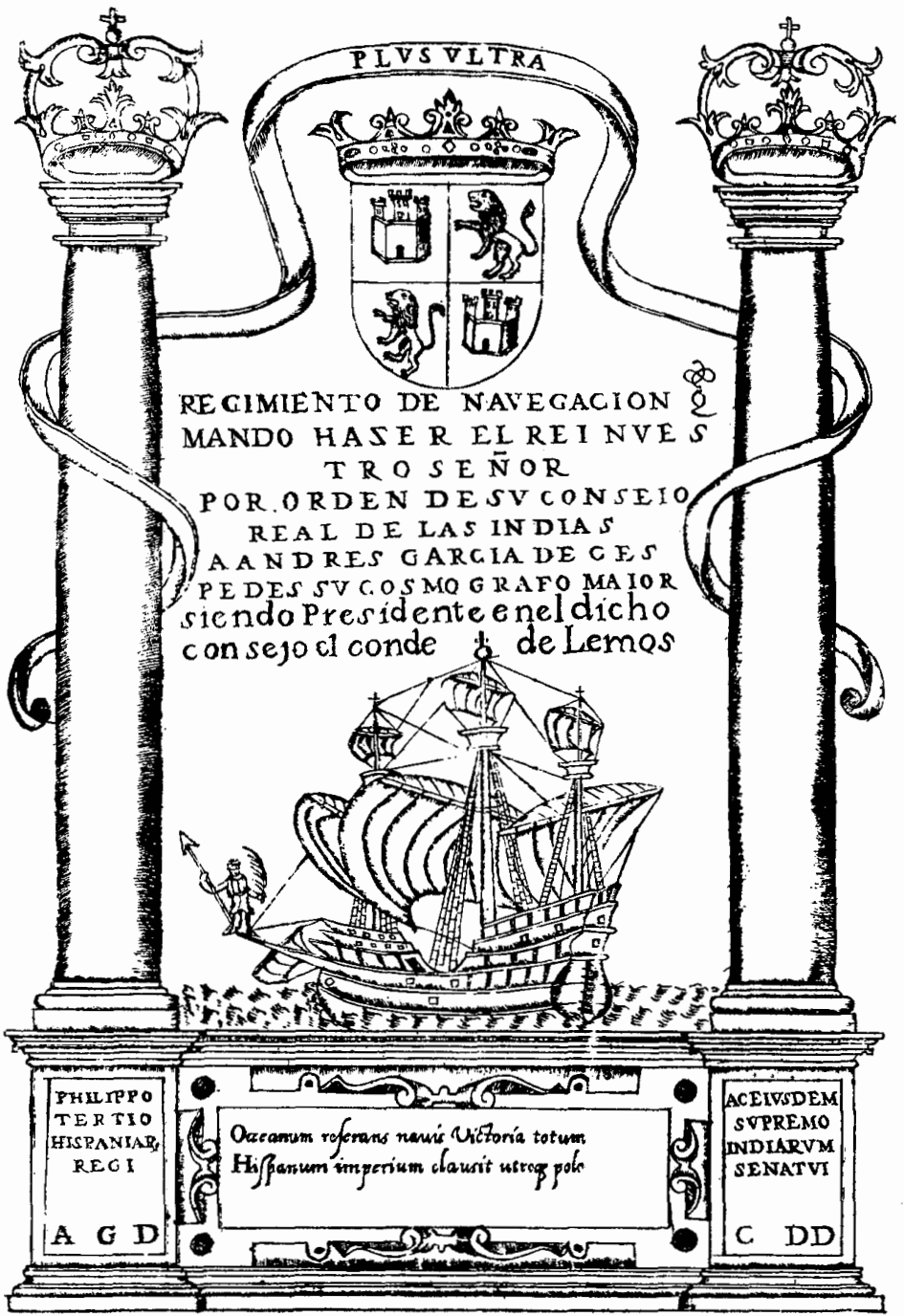

